\title{
Serological survey of bovine viral diarrhea (BVDV-1), brucellosis, and leptospirosis in captive white-lipped peccaries (Tayassu pecari) from the Midwest region in Brazil
}

\author{
Igor R.H. Gatto ${ }^{a}$, Ludimilla G. Di Santo ${ }^{a}$, Gabriel Y. Storino ${ }^{a}$, Luiz F. Sanfilippo ${ }^{a}$, \\ Marcio G. Ribeiro ${ }^{\mathrm{b}}$, Luis A. Mathias ${ }^{\mathrm{a}}$, Aulus C. Carciofi ${ }^{\mathrm{a}}$, Luís G. De Oliveira ${ }^{\mathrm{a}^{*}}$
}

\begin{abstract}
The present study was conducted to assess the occurrence of anti-Brucella sp., anti-BVDV-1, and anti-Leptospira spp. antibodies from captive white-lipped peccary (Tayassu pecari). A cross-sectional survey was performed testing 100 serum samples collected in a commercial breeding herd. All samples were submitted to the acidified antigen test (AAT), virus neutralization test (VNT) and microscopic agglutination test (MAT) with live antigens. None of the samples tested agglutinated in the AAT screening test. In the VNT, 28 samples presented a cytotoxic effect and were excluded from the evaluation. For BVDV-1, only one sample (1/72; 1.38\%) was positive, with antibody titers of 40. For leptospirosis, $9 \%$ (9/100) of the samples reacted to at least one of the 24 serovars tested, with 8\% (8/100) positive for serovar Patoc and 1\% (1/100) for serovar Grippotyphosa. The maximum titer observed was 100. The identification of antibodies against the serovars Patoc and Grippotyphosa suggests that the sampled individuals have been exposed to the pathogen at some point during their lifetime. Regarding BVDV-1, this may be the first serological survey to describe seropositive samples in tayassuids.

Key words: infectious disease, tayassuidae, zoonosis.
\end{abstract}

\section{INTRODUCTION}

Swine and peccaries belong to the Artiodactyla order and to the Suidae and Tayassuidae families, respectively. Two species of peccaries are found in Brazil, the Whitelipped peccary (Tayassu pecari) and the Collared peccary (Tayassu tajacu) (Keuroghlian and Eaton 2008). These two species of tayassuids are widely hunted in tropical forests to avoid their entry into certain regions and for the consumption by local communities (Bodmer et al 1996, Cullen, Bodmer and Valladares-Padua 2000, Altrichter and Boaglio 2004). Predatory hunting of peccaries has been motivated by their gregarious and occasional aggressive behaviour, besides food habits that promote the damage of grain and horticultural plantations (Oliver 1993). The reduction of ecological impact occasioned by predatory tayassuid hunting may be possible by implementing commercial, sustainable, conservationist alternatives for income generation for communities living in areas inhabited by those species (MMA 2001).

Studies regarding health aspects of tayassuids are important because they provide essential information considering the development and widespread captive breeding of peccary species in several Latin American

Received: 21.12.2018.

Accepted: 14.08.2019.

${ }^{a}$ School of Agricultural and Veterinary Sciences, São Paulo State University, Jaboticabal, São Paulo, Brazil.

bAmollis Consultoria Ambiental, Itapavi, São Paulo, Brazil.

'School of Veterinary Medicine and Animal Science, São Paulo State University, Botucatu, São Paulo, Brazil.

*Corresponding author: LG de Oliveira; Via de Acesso Prof. Paulo Donato Castellane s/n, Jaboticabal, São Paulo, 14884-900, Brazil; luis. guilherme@fcav.unesp.br countries (Nogueira and Nogueira-Filho 2011), taking into account the risks attributed and the environmental impact. Serological surveys conducted on T. pecari and T. tajacu populations revealed antibodies against Leptospira spp. (Ito et al 1998, Mayor et al 2006, Freitas et al 2010, Navas-Suárez et al 2017), vesicular stomatitis virus and pseudorabies virus (Corn 1987), Orbivirus spp. (Gerber et al 2012) and Brucella spp. (Corn 1987, Gruver and Guthrie 1996, Ito et al 1998, Mayor et al 2006) which are important agents causing infections in domestic pigs. Some molecular studies in T. pecari and T. tajacu have also detected antigens of Erysipelothrix rhusiopathiae (Coutinho et al 2012), Trypanosoma evansi e T. cruzi (Herrera et al 2008), porcine circovirus type 2, herpesvirus suis type 1, Mycoplasma hyopneumoniae and Pasteurella multocida (Castro et al 2014, Navas-Suárez et al 2017). To date, antibodies and molecular detection of bovine viral diarrhoea virus (BVDV) have been described exclusively in wild boars (Sedlak, Bartova and Machova 2008, Weber et al 2016).

Evidence has pointed to the risks of transmission of pathogenic agents among domestic swine, tayassuids and wild boars. Based on this assumption, the tayassuids may serve as susceptible hosts and potential reservoirs of agents that can infect domestic and wild pigs in addition to other species (Nava and Cullen 2003, Herrera et al 2008, Freitas et al 2010, Coutinho et al 2012). Freitas et al (2010) demonstrated the presence of anti-Leptospira interrogans antibody titers in $T$. pecari that maintained close interaction with local communities and other domestic animals, indicating that the close relationship among humans, domestic animals, and tayassuids resulted in the contact with the pathogen. In this scenario, the present study assessed the occurrence of antibodies against Brucella sp., BVDV-1 and 
Leptospira spp. in white-lipped peccary (Tayassu pecari) from a commercial breeder located in the Cerrado area, Central-Western region of Brazil.

\section{MATERIAL AND METHODS}

\section{STUDY SITE}

The study was conducted in a commercial farm (process Ibama ${ }^{\circ}$ 02001.004190/1999-54) composed of a set of properties located in the Cerrado area which has about $330 \mathrm{~km}^{2}$ bordering the state of Minas Gerais, state of Goiás and state of Bahia. The farm is dedicated to the commercial breeding of T. pecari, T. tajacu, Ema (Rhea Americana) and red-footed tortoise (Chelonoidis carbonaria). The tayassuids breeding on the farm began in 2001. In 2008, the facilities were restructured and animal nutrition was reformulated by increasing the capacity and number of animals within the picket in an intensive breeding system. Each animal species was bred at a different site and each site consisted of $180 \mathrm{~m}^{2}$ pickets, which housed groups of 6 to 10 animals. The pickets of the tayassuids consisted of an earthen floor without vegetation, surrounded by walls and fences over the walls. The pickets were located next to each other on both sides of a long corridor, and within them, there were feeders and water fountains (figure 1). This study was approved by the Ministry of the Environment (SISBIO n $56725-1$ ).

\section{ANIMALS}

In total, the property had $365 \mathrm{~T}$. pecari. The family groups and groups with defined hierarchy were considered the selection criteria for sampling and a total of 100 animals were sampled, 72 females and 28 males.

Animals from 14 pickets were collected and, of those, four pickets with ten animals per group (two pickets with animals between three and six months of age and two pickets with animals between seven and 10 months of age) and ten pickets of families with six animals per group (all ages). The number of animals sampled per group according to sex and age is presented in table 2 .

\section{SAMPLES}

In July 2017, the samples were collected in a single time point. For the blood sample collections, each group of animals was transferred to the management area. All

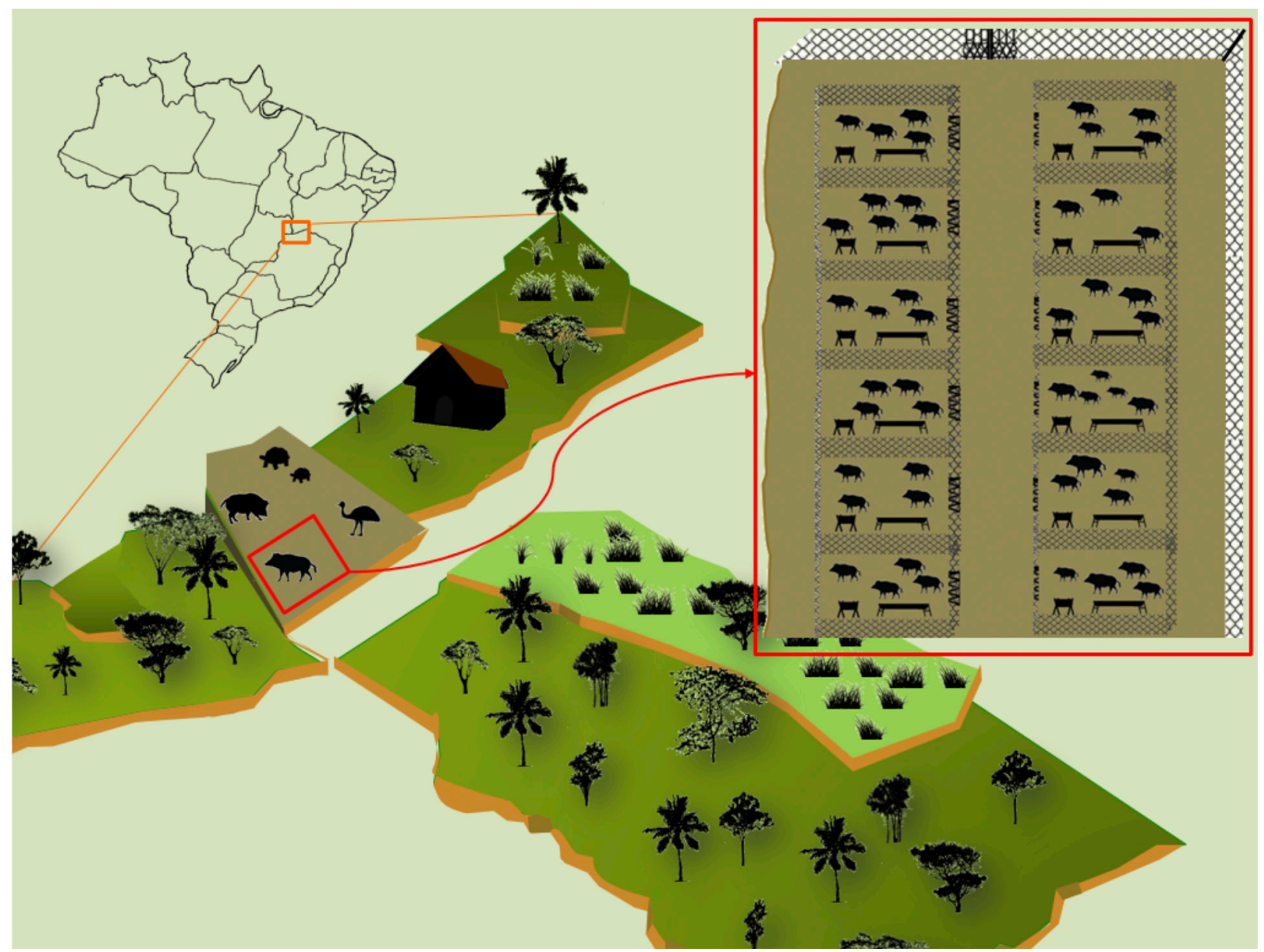

Figure 1. Schematic representation of the study site, surrounded by Cerrado vegetation and bordering the state of Minas Gerais, state of Goiás, and state of Bahia. In detail, the spatial organisation of Tayassu pecari pickets arranged side by side. 
Table 1. Frequency of anti-Leptospira agglutinins by microscopic agglutination test (MAT) in 100 Tayassu pecari and risk factor analysis for positive reactions by sex by Fisher's exact test $(P>0.05)$.

\begin{tabular}{lccc}
\hline \multirow{2}{*}{ Serogroup } & & \multicolumn{2}{c}{ Total positive reactions (\%) } \\
\cline { 3 - 4 } & & CI** 95(\%) & Maximum titer \\
\hline Patoc & $8(8 \%)$ & 7.94 to 8.05 & 100 \\
Grippotyphosa & $1(1 \%)$ & 0.17 to 5.44 & 100 \\
Icterohaemorrhagiae & $4(4 \%)$ & 1.56 to 9.83 & $50^{*}$ \\
Shermani & $1(1 \%)$ & 0.17 to 5.44 & $50^{*}$ \\
Butembo & $1(1 \%)$ & 0.17 to 5.44 & $50 *$ \\
Pyrogenes & $1(1 \%)$ & 0.17 to 5.44 & $50 *$ \\
Bratislava & $2(2 \%)$ & 0.55 to 7 & $50 *$ \\
Patoc & $16(16 \%)$ & 15.92 to 16.07 & $50 *$ \\
Overall & $100(100 \%)$ & & $P$-value \\
\hline Sex as a risk factor & Odds ratio & CI $95(\%)$ & 0.71 \\
\hline \multicolumn{1}{c}{ Male $(3 \mid 28)^{* * *}$} & 1.28 & 0.19 to 6.51 & \\
Female $(6 \mid 72)$ & &
\end{tabular}

*Reagents in the screening test (titer $<100)$.

**Confidence interval

****Positive for any serovar| total individuals by sex

Table 2. Distribution of males and females of Tayassu pecari collected in 14 pickets with three groups, submitted to serodiagnosis of brucellosis, bovine viral diarrhea and leptospirosis.

\begin{tabular}{|c|c|c|c|}
\hline \multirow{2}{*}{ Picket No. } & \multicolumn{2}{|c|}{ Individuals by gender } & \multirow{2}{*}{ Group } \\
\hline & Male & Female & \\
\hline 1 & 4 & 6 & \multirow{2}{*}{3 to 6 months } \\
\hline 2 & 3 & 7 & \\
\hline 3 & 4 & 6 & \multirow{2}{*}{7 to 10 months } \\
\hline 4 & 4 & 6 & \\
\hline 5 & 2 & 4 & \multirow{10}{*}{ Families } \\
\hline 6 & 1 & 5 & \\
\hline 7 & 1 & 5 & \\
\hline 8 & 2 & 4 & \\
\hline 9 & 1 & 5 & \\
\hline 10 & 2 & 4 & \\
\hline 11 & 1 & 5 & \\
\hline 12 & 1 & 5 & \\
\hline 13 & 1 & 5 & \\
\hline 14 & 1 & 5 & \\
\hline
\end{tabular}

animals had a microchip and earrings with a registration number for tracking information. In the management area, the animal was placed inside of a structure similar to a cattle chute, developed in an appropriate size for the mechanical restraint of $T$. pecari. The cage had side openings for accessing to the punctured region. A total of $10 \mathrm{ml}$ of blood of which animal was collected from the jugular, or cephalic or saphenous veins, prioritizing the easy access for each situation, in an attempt to avoid the animal excessive or prolonged stress. The blood sampling lasted on average two minutes per animal. The serum samples were identified and maintained at $-20{ }^{\circ} \mathrm{C}$, for further serological tests.

\section{LABORATORY PROCEDURES}

Acidified antigen test (AAT). The AAT was performed as recommended in the Manual of the National Program for the Control and Eradication of Animal Brucellosis and Tuberculosis (Brazil 2006). The method consists of 
placing $0.03 \mathrm{~mL}$ of the serum in contact with $0.03 \mathrm{~mL}$ of the antigen in a checkered glass plate followed by slight homogenisation, then keeping the plate in rotational and under constant movements until the moment of the reading, which was done four minutes after the reaction using a box with light (or agglutinoscope) to observe the formation of agglutination lumps. The antigen used in this technique was prepared with a Brucella abortus sample $1119 / 3$ at $8.0 \%$ cell volume, stained with Bengal rose, $\mathrm{pH}$ 3.65. The AAT tests, as well as the following tests, were applied following the recommendations for domestic pigs (Sus scrofa domesticus) and they were not standardised for T. pecari.

Viral neutralization test (VNT). The samples were submitted to the VNT for the detection of antibodies against BVDV-1a (Singer strain), as recommended by the Manual of Diagnostic Tests and Vaccines for Terrestrial Animals (OIE 2015) with modifications. All seropositive samples at screening were duplicated for repeatability of the result. On each plate, negative and positive controls were added. A sample was considered positive when the total neutralisation of $100 \mathrm{TCID}_{50}$ occurred in the serum and no cytopathic effect (CPE) was observed in the cell layer in serum dilutions higher than 1:10 (OIE 2015) with modifications. Antibody titers were expressed as the reciprocal of the highest dilution at which viral neutralisation was verified, and the final titer was the geometric mean of the titers found in the duplicates.

Microscopic agglutination test (MAT). The MAT was performed for the diagnosis of leptospirosis using a collection of live antigens that included 24 serological variants of pathogenic leptospires of the following serogroups (serotype representatives): Australis (Australis, Bratislava), Autumnalis (Autumnalis, Butembo), Ballum (Castellonis), Batavie (Batavie), Canicola (Canicola), Celledoni (Whitcombi), Cinoptery (Cinoptery), Grippotyphosa (Grippotyphosa), Hebdomadis (Hebdomadis), Icterohaemorrhagie (Copenhageni, Icterohaemorrhagiae), Javanica (Javanica), Panama , Pomona (Pomona), Pyrogenes (Pyrogenes), Sejroe (Hardjo, Wolffi), Shermani (Shermani), Tarassovi (Tarassovi), Djasiman (Sentot) and two saprophytic leptospires: Andamana (Andamana) and Seramanga (Patoc) (Lee et al 2017).

The screening was performed at 1:50 and 1:100 dilutions. In the presence of agglutination, the sera was titrated in two-fold serial dilutions. The titer was given as the reciprocal of the highest dilution, titers of 1:100 to 1:200 are considered low positive, interpreted as exposure to Leptospira spp., Titer $\geq 1: 400$ are considered high positive, indicating active or recent infection (Faine et al 1999, Boqvist et al 2002). Only cultures from 4 to 14 days, which did not present contaminants or autoagglutination, were used as antigens.

\section{STATISTICAL ANALYSIS}

A descriptive analysis of the frequency results was carried out, with the calculation of the respective confidence intervals. The association between sex and the number of seropositive for Leptospira spp. was analysed using the Fisher exact test $(P<0.05)$.

\section{RESULTS AND DISCUSSION}

In this study, none of the 100 serum samples of T. peccary tested had antibodies detectable by AAT for Brucella sp., thus, it was not necessary to perform confirmatory tests. Similar results were obtained in the northern and northeastern regions of Brazil, where researchers reported the absence of positive serological results for Brucella abortus in a group of 11 different species, including $T$. peccary (Minervino et al 2018). Previous data in the north of Brazil described $4.9 \%$ (2/41) of serum samples of T. tajacu reactive for Brucella sp., in a nursery with a history of infertility and mortality of the offspring, with the seropositive animals being euthanised due to sanitary issues (Mayor et al 2006, 2007). Therefore, epidemiological surveys studies regarding disease in tayassuids breeding are not clear regarding the possibility of such species serving as reservoirs or carriers of Brucella sp.

BVDV is a pestivirus that shows genetic and antigenic similarities to classical swine fever and other pestiviruses and has an important impact on cattle and pigs (Brodersen 2014). Out of the 100 samples submitted to VNT, 28 showed a cytotoxic effect and were excluded from the evaluation. For BVDV-1a, one animal was reactive 1/72 $(1.38 \%, \mathrm{CI}$ $95 \% 0.24$ to 4.45 ), with a titer of 40 . This animal was male, $48 \mathrm{~kg}$, belonging to the G8 group. In the literature, there is no evidence of the detection of antibodies against BVDV in T. pecari or T. tajacu. In the present study, only one sampled animal showed anti-BVDV antibodies.

In Brazil, Gatto et al (2016) and Gatto et al (2018) identified seropositivity for BVDV-1 and BVDV-2 in pig serum samples from intensive breeding from several Brazilian states. Almeida et al (2017) also detected BVDV-1 and BVDV-2 seropositive samples in non-technified rearing farms at the northeast of the state of São Paulo. Wild animals infected with BVDV are described as indicative of the presence of the virus in nearby herds located within a given region, although the role of tayassuids in the epidemiology of BVDV is unknown (Milićević 2018).

Serological diagnosis of leptospirosis showed that $9 \%$ of the T. pecari samples were reactive to several serovars at low titers (> 1/50): Patoc, Grippotyphosa, Itereohaemorrhagiae, Shermani, Butembo, Pyrogenes, and Bratislava. However, titers higher that $1 / 100$ were only found for serovar Patoc $8 \%(8 / 100)$ and $1 \%$ (1/100) for serovar Grippotyphosa, and no association was observed between sex and the occurrence of Leptospira spp. antibodies $(P>0.05)$. The 
occurrence of antibodies against Leptospira spp. in $T$. pecari was described by Ito et al (1998), in animals from Pantanal, the southern region of the state of Mato Grosso, which were reagents for the serovars Copenhageni, Icteratohaemorrhagiae IV, Panama, Patoc, and Autumnalis. In fragments of the Atlantic Forest located in the state of São Paulo, serum samples of T. pecari were seropositive to serovars Pomona and Icterohaemorrhagiae IV (Nava 2008). Freitas et al (2010) described the occurrence of the serovars Autumnalis, Pomona, Copenhageni, Canicola, Hardjo, Grippotyphosa, Icterohaemorrhagiae, Bataviae, Tarassovi, and Hebdomadis in T. pecari from an ecosystem interacting with cattle.

In Pantanal (southern region of the Mato Grosso state), Ito et al (1998) reported the occurrence of serovar Patoc. Seroreactivity for Butembo and Automnallis serovar was detected in pigs samples from Amazonas state (Brazil) (Mayor 2006, Mendoza et al 2007). In the same region, Amazonas state, a serological survey identified positive samples for Australis, Hebdomadis, Autumnalis, Bataviae, Djasiman, Grippothyphosa, Balum, Canicola, Mini, Tarassovi, and Icterohaemorragiae (Nava 2008). Pyrogenes and Patoc were described as the most prevalent in T. tajacu. In the Peruvian Amazon, seropositivity was reported for Iquitos, Australis, Hebdomadis, Icterohaemorrhagiae, Autumnalis, Tarassovi, Cynopteri, and Ballum (Jori et al 2009).

In the present study, serovar Patoc was the predominant serovar detected. The occurrence of antibodies against serovar Patoc was also described in Pantanal, southern region of the state of Mato Grosso in T. pecari and T. tajacu (Ito et al 1998) and only in T. tajacu by Nava (2008). Also, this serovar was described in wild boars in the state of São Paulo and Paraná (Marchiori Filho et al 2002). Only $1 \%$ of the animals were seropositive for Grippothyphosa, a result similar to that found by Freitas et al (2010) in $T$. pecari and by Mendoza et al (2007) in T. tajacu.

The emergence of human leptospirosis cases has been reported in several countries. The increase of human infections has been associated with increased exposure of the host to the pathogen, particularly during outdoor activities, sports practices or contact with wild animals. Thus, the sylvatic cycle of the disease is a growing concern for public health, justifying epidemiological surveillance studies regarding leptospirosis in different species of wild animals including tayassuids (Morgan et al 2002).

Reagent serum samples were identified for BVDV-1a and Leptospira spp. in T. pecari from a commercial breeder in the midwest of Brazil. As far as we know, this is the first serological survey to describe describe the presence of BVDV-1 (strain Singer) antibodies in T. pecari. Yet, we must also take into account that the diagnostic methods carried out are not standardised for Tayassu sp. species, and there may be false negatives and even false positives. To date, there is no consistent evidence supporting that BVDV can infect those wild species. Monitoring captive-reared wildlife is important to detect pathogen excretion which could affect human health and or other animals (wild or domestic) under production.

\section{ACKNOWLEDGEMENTS}

The authors would like to thank the farm owners and the staff of the Department of Preventive Veterinary Medicine and Animal Reproduction of the São Paulo State University (Unesp), School of Agricultural and Veterinary Sciences, Jaboticabal, São Paulo, Brazil.

\section{REFERENCES}

Almeida HMS, Gatto IRH, dos Santos ACR, Ferraudo AS, Samara SI, et al. 2017. A cross-sectional and exploratory geospatial study of bovine viral diarrhea virus (BVDV) infections in swines in the São Paulo State, Brazil. Pak Vet J 37, 470-474

Altrichter M, Boaglio GI. 2004. Distribution and relative abundance of peccaries in the Argentine Chaco: associations with human factors. Biol Conserv 116, 217-225.

Bodmer RE, Aquino R, Puertas P, Reyes C, Fang T, et al. 1996. Manejo y Uso Sustentable de Pecaríes en la Amazonia Peruana. No. 18. Comisión de Supervivencia de Especies, Lima, Perú.

Boqvist S, Thu HT, Vågsholm I, Magnusson U. 2002. The impact of Leptospira seropositivity on reproductive performance in sows in southern Viet Nam. Theriogenology 58, 1327-1335.

Brasil 2006. Programa Nacional de Controle e Erradicação da Brucelose e Tuberculose (PNCEBT). Manual Técnico. Ministério da Agricultura, Pecuária e Abastecimento (MAPA/SDA/DAS), Brasília, Brazil.

Brodersen BW. 2014. Bovine viral diarrhea virus infections: manifestations of infection and recent advances in understanding pathogenesis and control. Vet Pathol 51, 453-464.

Castro AMMG, Brombila T, Bersano JG, Soares HS, Silva SOS, et al. 2014. Swine infectious agents in Tayassu pecari and Pecari tajacu tissue samples from Brazil. J Wildl Dis 50, 205-209.

Corn JL, Lee RM, Erickson GA, Murphy CD. 1987. Serologic survey for evidence of exposure to vesicular stomatitis virus, pseudorabies virus, brucellosis and leptospirosis in collared peccaries from Arizona. $J$ Wildl Dis 23, 551-557.

Coutinho TA, Moreno AM, Imada Y, Lopez RPG, Neto JSF. 2012. Characterization of Erysipelothrix rhusiopathiae isolated from Brazilian Tayassu pecari. Trop Anim Health Prod 44, 689-692.

Cullen JRL, Bodmer RE, Valladares-Padua C. 2000. Effects of hunting in habitat fragments of the Atlantic forests, Brazil.Biol Conserv 95, 49-56.

Faine S, Aoler B, Bolin C, Perolat P. 1999. Leptospira and Leptospirosis. $2^{\text {nd }}$ ed. Medi Sci, Melbourne, Australia.

Freitas TPT, Keuroghlian A, Eaton DP, Freitas EB, Figueiredo A, et al. 2010. Prevalence of Leptospira interrogans antibodies in free-ranging Tayassu pecari of the Southern Pantanal, Brazil, an ecosystem where wildlife and cattle interact. Trop Anim Health Prod 42, 1695-1703.

Gatto IRH, Arruda AG, Almeida HMS, Silva GCP, Leite AI, et al. 2016. A cross-sectional study to estimate the frequency of anti-bovine viral diarrhea virus-1antibodies in domestic pigs of Mossoró region in the state of Rio Grande do Norte, Brazil. Cienc Rural 46, 1607-1612.

Gatto IRH, Linhares DCL, de Souza Almeida HM, Mathias LA, de Medeiros ASR, et al. 2018. Description of risk factors associated with the detection of BVDV antibodies in Brazilian pig herds. Trop Anim Health Prod 50, 773-778.

Gerber PF, Galinari GCF, Cortez A, Paula CD, Lobato ZIP, et al. 2012. Orbivirus infections in collared peccaries (Tayassu tajacu) in southeastern Brazil. J Wildl Dis 48, 230-232.

Gruver KS, Guthrie JW. 1996. Parasites and selected diseases of collared peccaries (Tayassu tajacu) in the trans-pecos region of Texas. $J$ Wildl Dis 32, 560-562.

Herrera HM, Abreu UGP, Keuroghlian A, Freitas TP, Jansen AM. 2008. The role played by sympatric collared peccary (Tayassu tajacu), 
white-lipped peccary (Tayassu pecari), and feral pig (Sus scrofa) as maintenance hosts for Trypanosoma evansi and Trypanosoma cruzi in a sylvatic area of Brazil. J Parasitol Res 103, 619-624.

Ito FH, Vasconcellos SA, Bernardi F, Nascimento AA, Labruna MA, et al. 1998. Evidência sorológica de brucelose e leptospirose e parasitismo por ixodídeos em animais silvestres do pantanal sul-mato-grossense. Ars Veterinaria 14, 302-310.

Jori F, Galvez H, Mendonza P, Cespedes M, Mayor P. 2009. Monitoring of leptospirosis seroprevalence in a colony of captive collared peccaries (Tayassu tajacu) from the Peruvian Amazon. Res Vet Sci 86, 383-387.

Keuroghlian A, Eaton DP. 2008. Fruit availability and peccary frugivory in an isolated Atlantic forest fragment: Effects on peccary ranging behavior and habitat use. Biotropica 40, 62-70.

Lee HS, Khong NV, Xuan HN, Nghia VB, Nguyen-Viet H, Grace D. 2017. Sero-prevalence of specific Leptospira serovars in fattening pigs from 5 provinces in Vietnam. BMC Vet Res 13, 125.

Marchiori Filho M, Girio RJS, Lui JF, Mathias LA, Brasil ATR. 2002. Estudo sorológico para leptospirose em populações de diferentes grupos genéticos de javalis (Sus scrofascrofa, Linnaeus, 1758) dos estados de São Paulo e Paraná. Arq Inst Biol 69, 9-15.

Mayor P, LePendu Y, Guimarães DA, Silva JV, Tavares HL, et al. 2006. A health evaluation in a colony of captive collared peccaries (Tayassu tajacu) in the Eastern Amazon. Res Vet Sci 81, 246-253.

Mayor P, Guimarães DA, LePendu Y, Da Silva JV, Jori F, et al. 2007. Reproductive performance of captive collared peccaries (Tayassu tajacu) in the eastern Amazon. Anim Reprod Sci 102, 88-97.

Mendoza P, Mayor P, Galvez HÁ, Cespedes MJ, Jori F. 2007.Antibodies against Leptospira spp. in captive collared peccaries, Peru. Emerg Infect Dis 13, 793-794.

Milićević V, Maksimović-Zorić J, Veljović L, Kureljušić B, Savić B, et al. 2018. Bovine viral diarrhea virus infection in wild boar. Res Vet Sci 119, 76-78.

Minervino AHH, Soares HS, Barrêto-Júnior RA, Neves KAL, Morini AC, et al. 2018. Antibodies against brucella abortus and Leptospira spp. in captive mammals in the states of pará and rio grande do norte, brazil. J Zoo Wildl Med 49, 355-360.

MMA, Ministério do Meio Ambiente. 2001. Avaliação e identificação de ações prioritárias para a conservação, utilização sustentável e repartição dos benefícios da biodiversidade da Amazônia brasileira. MMA, Brasília, Brazil.

Morgan J, Katz S, Manea H, Sasaki F. 2002.Outbreak of leptospirosis among triathlon participants and community residents in Springfield, Illinois, 1998.Clin Infect Dis 34, 1593-1599.

Nava A, Cullen L. 2003. Peccaries as sentinel species: conservation, health and training in Atlantic Forest Fragments, Brazil. Sui form Soundings PPHSG Newsletter 3, 15-16.

Nava AFD. 2008. Espécies sentinelas para a Mata Atlântica: as conseqüências epidemiológicas da fragmentação florestal no Pontal do Paranapanema. Tese doutorado, Universidade de São Paulo, São Paulo, Brazil.

Navas-Suárez PE, Soler-Tovar D, Montenegro O. 2017. Los macro y microparásitos reportados para pecaríes y su importancia en la interfaz con especies de producción. In: Diego Soler-Tovar (ed). Conexiones de la salud global: ecosistemas, animales y humanos. Ediciones Unisalle, Bogotá D.C., Colombia, Pp 247-272.

Nogueira SS, Nogueira-Filho SL. 2011. Wildlife farming: an alternative to unsustainable hunting and deforestation in Neotropical forests? Biodiversity Conserv 20, 1385-1397.

Oliver WLR. 1993. Pigs, peccaries and hippos. IUCN, Gland, Switzerland.

Sedlak K, Bartova E, Machova J. 2008. Antibodies to selected viral disease agents in wild boars from the Czech Republic. $J$ Wildl Dis 44, 777-780.

Weber MN, Pino EHM, Souza CK, Mósena ACS, Sato JPH, et al. 2016. Primeira evidência da infecção pelo vírus da diarreia viral bovina em javalis. Acta Sci Vet 44, 1398.

OIE, World Organization for Animal Health 2015. Bovine viral diarrhoea. In: Drew T (ed). Manual of diagnostics tests and vaccines for terrestrial animals. OIE, Paris, France, Pp 698-710. 